\title{
CAMBRIAN BIOGEOGRAPHY OF THE PERIGONDWANA FAUNAL REALM
}

\author{
Wen T. CHANG \\ Nanjing Institute of Geology and Palaeontology. Academia Sinica. Chi-Ming- \\ Ssu. 39 East Bcijing Road. Nanjing, 210008. P. R. China. \\ E-mail: wtchang@juno.com
}

Chang, W.T. 1998. Cambrian biogeography of the Perigondwana Faunal Realm. [Biogeografía del Cámbrico del Reino faunístico de Perigondwanal. Revista Española de Paleontologia, n• extr. Homenaje al Prof. Gonzalo Vidal, 35-49. ISSN 0213-6937.

\begin{abstract}
The Cambrian Perigondwana Faunal Realm includes the Mediterranean region (Morocco, Spain, South France, Sardinia and Jordan) and Central Europe (Doberlug and Görlitz, both in Germany) during the Early and Late Cambrian time; and the Near East. Central, South and Southeast Asia, China, Korea, Australia and Antarctica from Early to Late Cambrian time. In Altai-Sayan and western Mongolia there is faunal overlap of Redlichioid and Olenellioid Faunal Provinces as in Morocco and Spain. The areas of overlap are widely separated by areas of no known overlap and the time duration is small.

Lower Cambrian genera of the Superfamily Redlichioidea, Middle Cambrian genera of Families Proasaphiscidae, Dorypygidae. Dolichometopidae and Oryctocephalidae, late Middle and early Late Cambrian genera of the Superfamily Damesellioidea and late Late Cambrian genera of the Superfamilies Leiostegioidea and Ptychaspidioidea are the bases for defining the Perigondwana Faunal Realm. Some open-shelf agnostid and polymerid genera are also used. At the same time, the boundaries between the Mediterranean and the AcadoBaltic Faunal Provinces and the palaeogeography of the Near East and South Asia are discussed. The appearance of Paradoxides-fauna in North Africa and the Mediterranean region is explained.
\end{abstract}

Key words: Cambrian, trilobites, biogeography, Perigondwana Faunal Realm.

\section{RESUMEN}

El Reino Faunístico de Perigondwana en el Cámbrico incluye el área mediterránea (Marruecos, España, sur de Francia, Cerdeña y Jordania) y la Europa central (Doberlug y Görlitz, en Alemania) durante el Cámbrico Temprano y Cámbrico Tardío; así como Oriente Próximo, Asia central, meridional y suroriental, China, Corea, Australia y la Antártida durante todo el Cámbrico. En là región de Altai-Sáyan y en Mongolia occidental se dá el solapamiento de las provincias faunísticas de los redlichioideos y de los olenelioideos, al igual que en Marruecos y España. Estas áreas de solapamiento están separadas por amplias áreas sin solapamiento conocido y son de una duración cortá.

Las bases paleontológicas que sirven para definir el Reino Faunístico de Perigondwana son géneros de trilobites del Cámbrico Inferior de la Superfamilia Redlichioidea, géneros del Cámbrico Medio de las familias Proasaphiscidae, Dorypygidae, Dolichometopidae y Oryctocephalidae, géneros del Cámbrico Medio tardío y Cámbrico Tardío temprano de la Superfamilia Damesellioidea, y géneros del Cámbrico Tardío tardío de las superfamilias Leiostegioidea y Ptychaspidioidea. También se emplean para ello algunos géneros de agnóstidos y polímeros de plataforma abierta. Al mismo tiempo, se discuten los límites entre las provincias faunísticas Mediterránea y Acado-Báltica y la paleogeografía de Oriente Próximo y Asia meridional. También se explicá la aparición de la fauna de Paradoxides en el área mediterránea.

Palabras clave: Cámbrico, trilobites, biogeografía, Reino faunístico de Perigondwana.

\section{INTRODUCTION}

Based on present-day geography, the distribution of the Cambrian trilobites around the world suggests two large first-level faunal realms from Early to Late Cambrian time (Cowie,1971; Chang, 1989). Study of the distribution of Cambrian trilobite genera suggests that the Perigondwana Realm (Kobayashi, 1976; Palmer and Repina, 1993), or the western Pacific Realm (Chang, 1989), has rather precise boundaries and can be recognized on the basis of several endemic families or superfamilies of trilobites. 


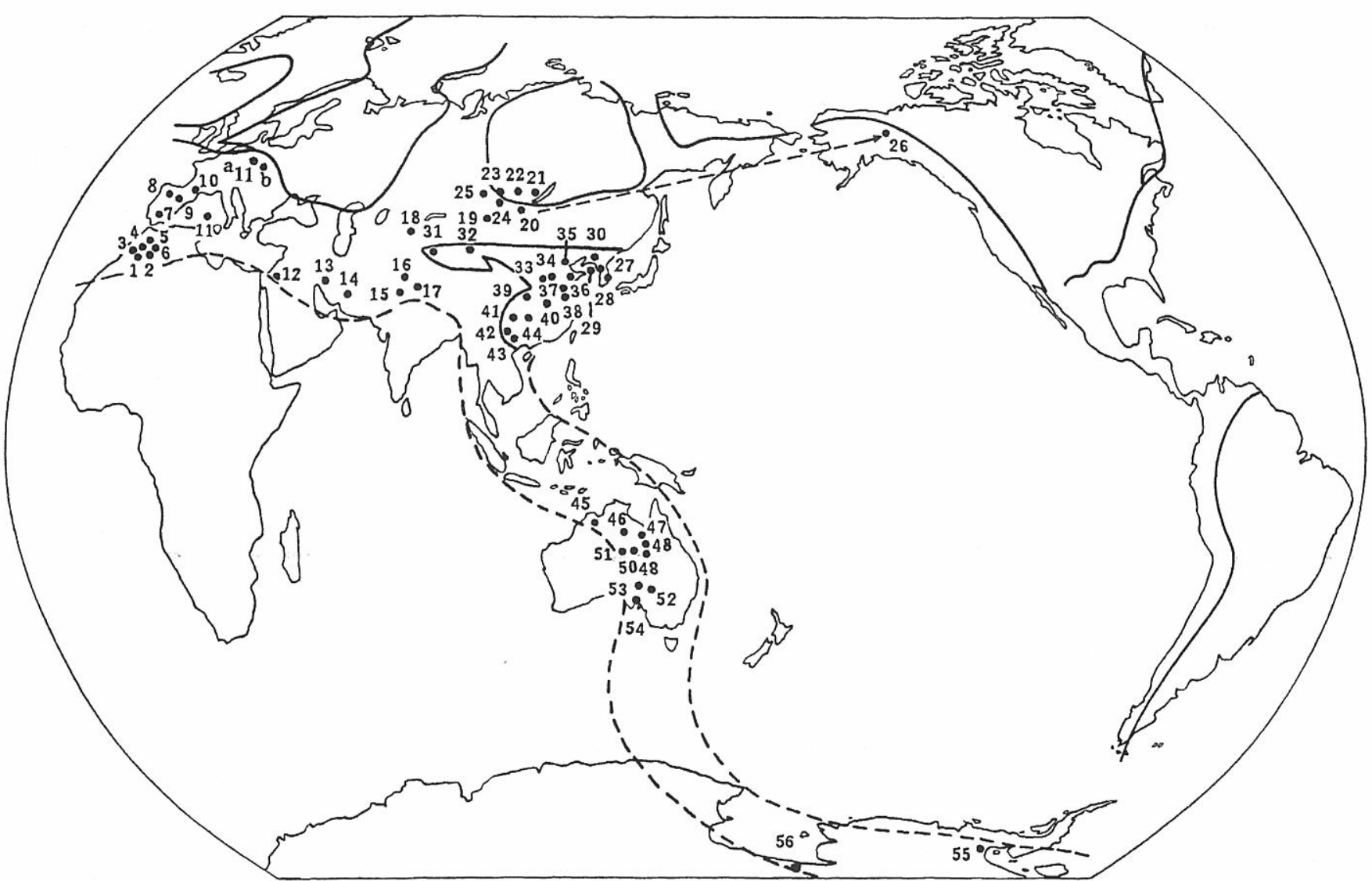

Figure 1. Biogeography of Redlichioidea (Early Cambrian) trilobites. 1. Ouijjane, southern Morocco. Resserops, Richterops, Abadiella (Hupé, 1953). 2. Timghit, southern Morocco. Pareops, Gigantopygus, Perrector, Clariondia, Longianda, Peudosaukianda (Hupé, 1953). 3. Amouslek, southern Morocco. Richterops, Resserops, Neoredlichia, Marsaisia (Hupé, 1953). 4. Tazemmourt, southern Morocco. Pararedlichia (=Eoredlichia) (Hupé, 1953). 5. Lemdad, Ounein, southern Morocco. Lemdadella (Sdzuy, 1978). 6. Tiout, southern Morocco. Resserops (Hupé, 1953). 7. Alanís (province of Sevilla), south-western Spain. Lemdadella, Saukianda, Perrector (Richter and Richter, 1941a; Henningsmoen, 1958; Liñán and Sdzuy, 1978). 8. a) Los Barrios de Luna (province of León), northern Spain. Dolerolenus, Lunolenus, Metadoxides. b) Concha de Artedo (province of Oviedo), northern Spain (Atlantic coast). Dolerolenus, Pararedlichia. c. Hermida (province of Lugo), northern Spain. Dolerolenus, Pararedlichia (=Eoredlichia). (Liñán and Sdzuy, 1978; Sdzuy, 1961). 9. Huérmeda, near Calatayud (province of Zaragoza), northeastern Spain. Redlichia (Sdzuy, 1961). 10. Montagne Noire, southern France. Galloredlichia (=Eoredlichia) (Courtessole and Jago, 1980). 11. Sardinia, Italy. Sardoredlichia, Nebidella, Eoredlichia, Sardaspis, Metadoxides, Enantiaspis, Dolerolenus, Iglesiella, Yiliangella (Pillola, 1991). 11. a) Doberlug; b) Görlitz; southeastern Germany. Dolerolichia, Ferralsia (Sdzuy, 1962; Geyer and Elicki, 1995). 12. Chirbet et-Burdsch, Sö, Ghor es-Safi, Jordan. Redlichops (Richter and Richter, 1941b). 13. Zagros Mountains, Western Isfahan, Iran. Redlichia (King, 1937; Wolfart, 1983). 14. Darreh Sangi, Rizu and Chabdjereh, Kuhbana, NW Kerman, Iran. Redlichia (Wolfart, 1974a). 15. Salt Range, Pakistan. Redlichia (Schindewolf and Seilacher, 1955). 16. Kashmir, Redlichia (Kobayashi, 1967). 17. Spiti. Redlichia (Reed, 1910). 18. Malayj Karatau, southern Kazakhstan. Redlichia, Ushbaspis (= Metaredlichioides) (Keller and Pokrovskaya, 1965). 19. Akbashi, $40 \mathrm{~km}$ NE Khobdo, western Mongolia. Redlichia, Sajanaspis, Judomia (olenelloid) (Korobov, 1989). 20. South Khubsugul region, Mongolia. Bulaiaspis, Redlichia, Elganellus, Chengkouaspids (Korobov, 1989). 21. Irkutsk, Russia. Tungusella, Bulaiaspis, (Repina, 1960). 22. East Sayan, Russia. Irgitkhemia, Olgaspis, Tungusella, Terechtaspis, Kolbaspis, Sajanaspis (Repina, 1960; 1979). 23. West Sayan, Russia. Sajanaspis, Inella, Terechtaspis, Redlichina (Repina, 1960, 1966; Repina et al., 1964). 24. Tuva, Russia. Irgitkhemia, Menneraspis, Sajanaspis, Terechtaspis (Tschernysheva, 1977; Pokrovskya, 1959; Repina, 1960, 1966). 25. Altai, Russia. Redlichina, Inella, Belliceps, Elganellus (Lermontova, 1940; Repina et al., 1964; Repina, 1966). 26. Yukon River (Water Level) area, Alaska, U.S.A. Churkinia (Palmer, 1968). 27. Chuwa, North Korea. Redlichia (Chang, 1988). 28. Bunkei, South Korea. Redlichia (Chang, 1988). 29. Liaodong Peninsula, Liaoning, China. Redlichia (Chang, 1988). 30. Taizihe Valley, Liaoning, China. Redlichia (Chang, 1988). 31. Keping, Xinjiang, western China. Redlichia (Chang, 1988). 32. Qurug Tagh, Xinjiang, western China. Ushbaspis (=Metaredlichioides), Parazhenbaspis (Zhu and Lin, 1983). 33. Zhongtiaoshan and Hejin district, southern Shanxi, China. Redlichia (Chang, 1988). 34. Jixian, northern Henan, China. Redlichia (Chang, 1988). 35. Kaiping Basin, eastern Hebei, China. Redlichia (Chang, 1988). 36. Central Shandong and northern Jiangsu, China. Neoredlichia, 
At the beginning of the Cambrian, the seas of the world were already populated by a diverse biota that included representatives of most of the major invertebrate phyla, as shown by the Chengjiang fauna of eastern Yunnan. The Arthropoda of the Cambrian include, first and foremost, the Trilobita. This was the largest and most diverse group of Cambrian organisms and apparently occupied most normal marine environments. It included open-ocean planktonic representatives, as well as restricted vagile benthos. Trilobites are the most commonly encountered Cambrian fossils and are the group from which almost all biogeographic data have been derived. Other Arthropoda are relatively rare. Some important superfamilies, such as, Redlichioidea, Dameselloidea, and some genera of the Leiostegioidea and Ptychaspidoidea, as well as genera of other families mentioned below, define the Perigondwana Faunal Realm.

\section{BIOGEOGRAPHY AND PHYLOGENY OF THE REDLICHIOIDEA}

\section{Biogeography}

(Fig. 1). This superfamily contains 136 genera and is confined to the Early Cambrian. More than half the genera occurred on the China Platform, especially in the Yangtze platformal area. Most genera of this group of trilobites were confined in China to the western Subprovince of the Yangtze, or Southwest China Platform (Chang et al., 1980). Most genera of the Metaredlichiinae and Yinites, Parayinites, Qingkouia, Paokannia, Parapaokannia and Meitanella of the Yinitidae which are always associated with protolenids and eodiscoids, occur in the Central Subprovince. In the eastern Subprovince or in the northern, or northwestern marginal part of the Chiangnan Belt, more or less equivalent to the upper part of the slope biofacies, very rare specimens of Redlichia may be found but they are always with a small cranidium and relatively thin exoskeleton, while in the southeastern parts of the Chiangnan belt which may represent the lower part of the continental slope, redlichiid trilobites disappeared entirely. Based on ecological studies, the Archaeocyatha which flourished best in the Early Cambrian sediments of the Central subprovince lived in marine, benthic, warm and shallow-water (20-50 m; Hill, 1972). If this data is reliable, the depth of sea-water in the western subprovince may be from zero to $20 \mathrm{~m}$ where most genera of the Wutingaspinae, Pararedlichinae, Redlichinae, Yiliangellinae, and of the Mayiellidae, Dolerolenidae, as well as some paedomorphic Yinitidae (Drepanopyge, Drepanuroides, Yunnanaspidella and Yunnanaspis) and the Chengjiang biota occurred. The depth of sea-water in the Eastern subprovince, or along the eastern Yangtze platformal margin may be 50-100 m, and the upper part of the continental slope is estimated to be 100 to $150 \mathrm{~m}$. In North and Southwest China, Cambrian rocks including oolitic limestones, varicolored suite of brick-red to violet argillaceous dolomitic limestones, red sandy shales, pseudomorphic crystals of salt as well as thick rock salt deposits of late Early and early Middle Cambrian age suggest a warm climate during the Cambrian. Thus distribution of redlichiid trilobites in Southwest China is mainly controlled by depth of sea water and temperature. Most species of redlichiids were found in sandstone, yellow or green shales and limestones which represent the normal deposits within the continental shallow shelf; only a few species of, for instance, Metaredlichia, Wutingaspis, Parabadiella in Southwest China, and species of Redlichia associated with Hsuaspis in Kangaroo Island of Australia, may occur in both the black and yellow or green shales, near the marginal part of, or within, the platform.

Redlichia (Chang, 1988). 37. Huainan, northern Anhui, China. Redlichia, Leptoredlichia (Chang, 1988). 38. Nanjing, Jiangsu and Chuxian, northern Anhui, China. Redlichia, Paokannia (Chang, 1988). 39. Southern Shaanxi and northern Sichuan, China. Redlichia, Paokannia, Mayiella, Drepanopyge, Paramalungia, Shatania, Yiliangella, Malungia, Eoredlichia, Wutingaspis, Parabadiella (Chang, 1988). 40. Yichang, Hubei, China. Redlichia, Metaredlichia (Chang, 1988). 41. Emei, Sichuan, China. Redlichia, Ushbaspis, Yiliangella, Changshanaspis, Chaoaspis, Wutingaspis (Chang, 1988). 42. Eastern Yunnan and southwestern Sichuan, China. Redlichia, Conoredlichia, Mayliella, Drepanuroides, Drepanopyge, Yunnanaspidella, Yunnanaspis, Yiliangella, Paramalungia, Malungia, Eoredlichia, Wutingaspis, Kuanyangia, Supushania, Chengjiangaspis, Parabadiella (Chang, 1966, Chang et al., 1980). 43. Southeast Yunnan, China. Redlichia, Metaredlichia, Yinites (Luo, 1984; Chang, 1966$) .44$. Northern Guizhou and Southeastern Sichuan, China. Redlichia, Drepanuroides (Chang, 1988). 45. Mount Panton, Northern Territory, Australia. Redlichia (Öpik, 1970). 46. Gum Ridge at Tenant Creek, Northern Territory, Australia. Redlichia (Öpik, 1970). 47. Yelvertoft Bed Locality M426, northwestern Queensland, Australia. Redlichia (Öpik, 1970). 48. Cornford Bore Locality M262, west of Mt. Isa, northwestern Queensland, Australia. Redlichia (Öpik, 1970). 49. Localities D41 and D131, Urandangi Area, western Queensland, Australia. Redlichia (Öpik, 1970). 50. Dinner Creek, Tobermory Area, SE Northern Territory, Australia. Redlichia (Öpik, 1970). 51. Locality AS 59, Phillipson Pound, Alice Springs Area, S Northern Territory, Australia. Redlichia (Öpik, 1970). 52. Mount Wright, White Cliffs Area, New South Wales, Australia. Redlichia (Öpik, 1970). 53. Wirrealpa Limestone, Flinders Ranges, South Australia, Australia. Redlichia, Xelà, Emuella, Balcoracannia, Parabadiella huoi, Pararaia (Öpik, $1970 ;$ Jell in Bengtson et al., 1990). 54. Yorke Peninsula and Kangaroo Island, South Australia, Australia. Redlichia, Dolerolenus sp. Parabadiella, Emuella, Balcoracannia, Eoredlichia, Pararaia, Yorkella, (Öpik, 1970; Jell in Bengtson et al., 1990). 55. Boulder from Mount Spann, Antarctica. Redlichia, Australaspis (Palmer and Gatehouse, 1972). 56. Mt. Bowers, Antarctica. Lemdadella (Palmer and Rowell, 1995). 


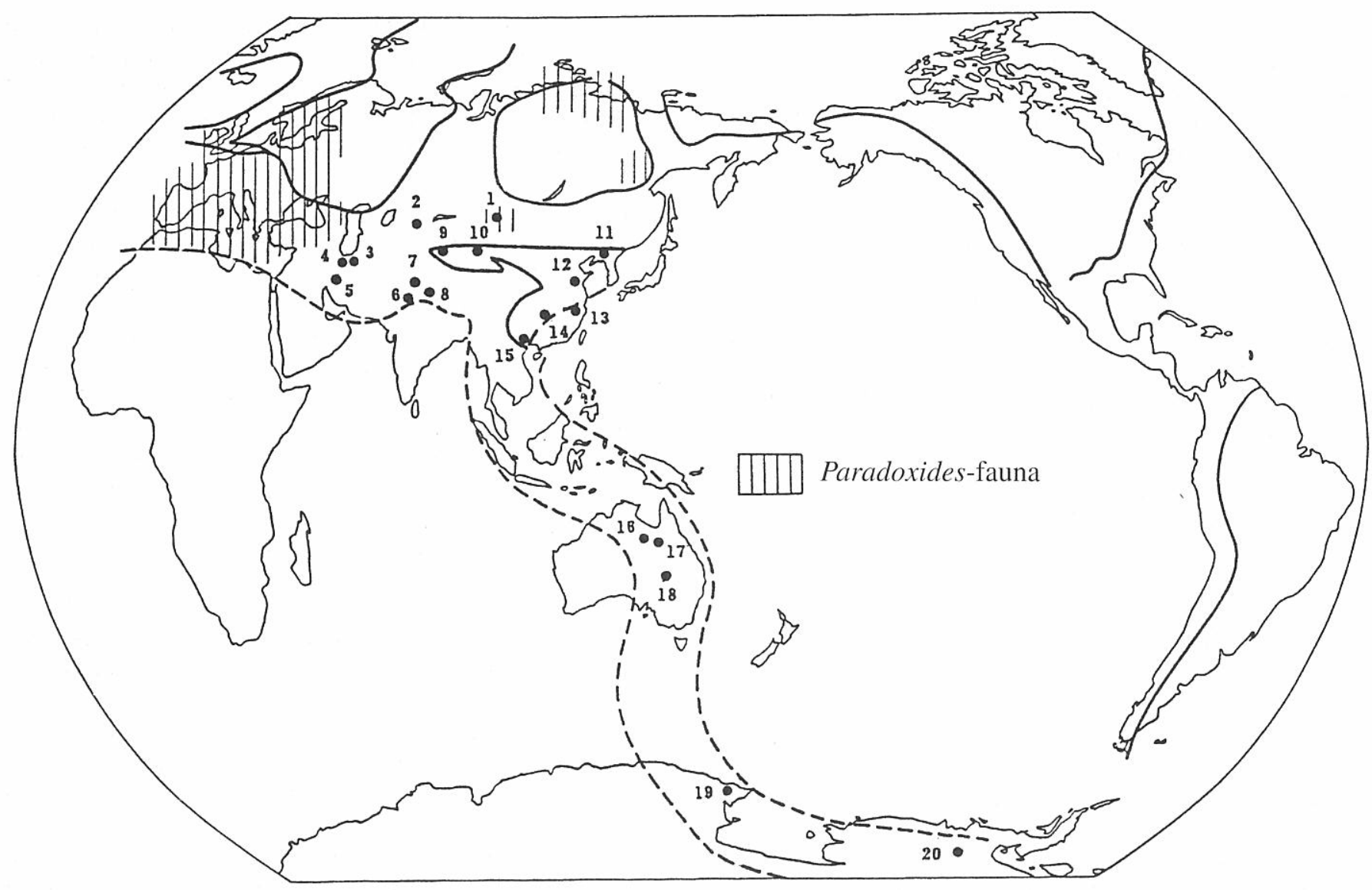

Figure 2. Middle Cambrian biogeography of the Perigondwana Realm. 1. Khobdo, western Mongolia; Paradoxides, Eccaparadoxides, Hydrocephalus, and Solenopleura (Dumicz et al., 1970; Chang, 1980; 1988). 2. Malyj Karatau, southern Kazakhstan. Agnostid trilobites are the same as in western hunan and western Zhejiang, South China; polymerid trilobites are also the same as in China. Genera are listed as follows: Wanshania (=Peichiashania, Ergaliev, 1980), Blackweldera, Palaeadotes, Ajrikina (=Jiangnania), Fuchouia, Lisania, Lisaniella, Prodamesella, Meringaspis karatauensis Ergaliev, 1980 (=Paradamesops karatauensis Ergaliev, 1980), Prohedinia, Platylisania, Dorypyge, Solenoparia, Maotunia, Tonkinella, Manchuriella, Honanaspis, Proasaphiscus (Ergaliev, 1980; Abdulin and Chakabaev, 1984; Abdulin et al., 1990). 3. Mila-Kuh, Shahmirzad; Hasanakdar; northern Iran. Dorypyge, Iranoleesia (Kushan, 1973). 4. Abhar; Sanghabad and Qanli-Chapoghlu; northern Iran. Dorypyge, Iranoleesia, (Kushan, 1973). 5. Ma'dan, 290 km northwest of Shiraz, Iran. Iranoleesia, Anomocarella. (Fortey and Rushton, 1976). 6. Salt Range, Pakistan. Chittidilla (Schindewolf and Seilacher, 1955). 7. Kashmir. Hundwarella, Tonkinella (Kobayashi, 1967). 8. Spiti. Orytctocephalus, Ptychoparia (Reed, 1910). 9. Keping, Xinjiang, western China. Kunmingaspis, Chittidilla (Lin et al., 1990). 10. Qurug Tagh, Xinjiang, western China. Dorypyge, Fuchouia, Amphoton, Lisania, Paradamesops, Paradamesella, Prodamesella, and Eoshengia (Lin et al., 1990). 11. Taitzuhe, northeastern China. Damesella, Lisania, Dorypyge, Amphoton, Fuchouia, Crepicephalina, Bailiella, Manchuriella, Proasaphiscus, and Shantungaspis (Chang, 1988). 12. Central Shantung, eastern China. Damesella, Leiopeishania, Fuchouia, Amphoton, Dorypyge, Taitzuia, Anomocarella, Crepicephalina, Lioparia, Proasaphiscus, Poriagraulos, Hsuchuangia, Shantungaspis, and Yaojiayuella (Chang, 1988). 13. Western Zhejiang, eastern China. Fuchouia, Prohedinia, Buttsia, Paradamesella (Lu and Lin, 1989). 14. Western Hunan, South China. Agnostid trilobite genera are mentioned in the text; polymerid trilobite genera are listed as follows: Prohedinia, Fuchouia, Wanshania, Palaeadotes, Dorypyge, Lisania, and Eoshengia (Song, 1989). 15. Southeast Yunnan. Solenoparops, Taitzuia, Amphoton, Damesella, Inouyella, Kaotaia, Oryctocephalus, Tonkinella, Bailiella, Lioparia, Wuania, Kunmingaspis, Mengzia, and Plesiagraulos (Luo, 1984). 16. Eastern part of Northern Territory, Australia. Oryctocephalus, Xystridura (Öpik, 1975; Shergold, 1969). 17. Western Queensland, Australia. Oryctocephalites, Xystridura, Pagetia, Amphoton, Fuchouia, Dorypyge, Mapania, Prohedinia (Öpik, 1961, 1975, 1982; Shergold, 1969). 18. Western New South Wales, Australia. Xystridura (Öpik, 1975). For agnostid trilobite genera in Australia, see Öpik (1979). 19. North Victoria Land, Antarctica. Dorypyge, Fuchouia, Solenoparia (Cooper and Shergold, 1991). 20. Ellsworth Mountains, Antarctica. Damesellidae, Fuchouia, Pagetia (Jago and Webers, 1992). 


\section{Phylogeny}

Genera of the Pararedlichiinae, Wutingaspiinae and Metadoxididae occur in the Chiungchussuan and genera of the Yinitidae, Mayiellidae, Metaredlichiinae, Kueichowiidae and Yiliangellinae in the early Tsanglangpuan age. Mianxianella, Kepingaspis and Wengangaspis of the Wutingaspiinae are of early Tsanglangpuan age, while Metaredlichia and Zhenbaspis in China and Iglesiella in Sardinia, of the Metaredlichiinae, may be late Chiungchussuan. Redlichiinae and Neoredlichiinae occur in the Upper Tsanglangpuan and Lungwangmiaoan. The Wutingaspiinae, (Wutingaspis), Pararedlichiinae (Eoredlichia) and Redlichiinae [Redlichia (Redlichia) and $R$. (Pteroredlichia)] represent a peramorphic evolutionary trend of the Redlichiidae from early to late Early Cambrian in Southwest China. Peramorphosis involves the eye lobe moving toward the glabella, anterior branches of the facial sutures becoming increasingly divergent, frontal glabellar lobe increasing in size as later species reach the protraction stage, genal angle moving anteriorly, pleural spines becoming increasingly longer, pygidial axial lobe becoming smaller and shorter, and two pairs of hypostomal spines becoming shorter or disappearing. These genera of the Yinitidae were derived from earlier Wutingaspis-like trilobites of the Chiungchussuan. The paedomorphic reduction in number of thoracic segments in these genera of the family Yinitidae is accompanied by a progressive increase in size of pygidium, by increase in pygidial spinosity and by increase in dorsal exoskeletal size. The Yinitidae is regarded as a miomeric off-shoot of the stem-form Redlichiidae by paedomorphosis. Because Neoredlichia and Leptoredlichia are very rare, the evolutionary relationship of Neoredlichiinae within the Redlichiidae is not known. Neoredlichiinae is almost exclusively a North China and Northern Korea subfamily and is one of the two phylogenetically terminal groups of the Redlichiidae.

The Gondwana and Perigondwana Realm for Redlichioid trilobites includes present-day eastern Asia, western Mongolia, parts of the south Siberian foldbelt, Kazakhstan, Middle South Asia (Kashmir, Pakistan, Iran, Afghanistan), the Near East, the Mediterranean region, Central Europe, North Africa, Australia and Antarctica. Kobayashi (1972) proposed the term Intermediate Faunal Province for the relatively small areas where there is faunal overlap of the Redlichian and Olenellian Provinces in Morocco, Spain, southern Siberia and western Mongolia (Korobov, 1989). Kobayashi (1987a) and the author (Chang, 1989) do not agree with the term Intermediate Faunal Province because definition of its boundaries will always be uncertain and the areas of overlap are widely separated by areas of no known overlap, and because the time duration of overlap is small.

\section{BIOGEOGRAPHY OF EARLY CAMBRIAN ARCHAEOCYATHIDS}

Based on Chinese Early Cambrian Archaeocyathids, Yuan and Zhang (1983) suggested that the Tienshan-
Altai-Great Khingan Geocline (Chang, 1988: fig. 1, Unit VII) should be referred to the Siberian Faunal Povince where the Ethmophyllidae flourished. However, the Coscinocyathidae, which dominated the China platform, especially the Southwest China platformal area, are intimately related to the Mediterranean region. Yuan and Zhang (1983) also mentioned that, during the Cambrian, China may have been situated near the equator, and that Siberia and Australia were located within the subtropical zones on both sides of the equatorial region, because of the presence of the Ethmophyllidae also in Australia. Debrenne (1992) suggested three Archaeocyathid faunal provinces, as follows: 1) the Afro-European Province, which may extend to China and Kazakhstan, characterized by Anthomorphidae; 2) the Australo-Antarctica Province, with Flindersicyathidae, Metacyathidae and Syringocnemididae; and 3) the Siberian Province, where all these families are represented.

\section{MIDDLE CAMBRIAN BIOGEOGRAPHY OF THE PERIGONDWANA REALM}

(Fig. 2). Although olenelloid trilobites have been found in Morocco, Spain and Germany, Early Cambrian redlichioid trilobites seem to dominate in the Mediterranean region and Central Europe, as mentioned above. During the Middle Cambrian, the Mediterranean region and Central Europe were dominated by Paradoxidoidea, such as Paradoxides (Eccaparadoxides), P. (Acadoparadoxides), Luhops and Hydrocephalus, and by European endemic Ptychoparioidea, for instance, Ptychoparia, Sao, Jincella, Badulesia, Conocoryphe, Ctenocephalus, Solenopleura and Solenopleurina. At the beginning of the Middle Cambrian, genera of eastern Asiatic affinities were entirely absent in the Mediterranean region and Central Europe, except Dorypyge which occurred in eastern Turkey, Sweden, Spain and probably South France (Thoral, 1935; Sdzuy, 1961; Dean, 1982). To the east of Turkey and south of the Alpine-Himalayan foldbelt, so far, there are no typical paradoxidoid trilobites in the Middle Cambrian. A Paradoxidoid trilobites fauna including Eccaparadoxides oelandicus, E. insularis, E. mongolicus, Hydrocephalus carens and Solenopleura sp. has been described and illustrated by Wojcik (in Dumicz et al., 1970), from the Middle Cambrian rocks of the Khobdo region, western Mongolia. Thus I am convinced that an open marine connection existed between western Mongolia and the Paradoxidoid Province, possibly by two routes, one across the Siberian Platform in the north, and the other to the Mediterranean region in the west through Central Asia, the Alborz Mountains in northern Iran, the Caucasus and Turkey, where a deep sea-way existed just north of the margin of Gondwanaland.

Middle Cambrian trilobites of Baltic aspect were evidently indigenous to the deep outermost shelf or upper basin slope, whereas those of western United States, western Queensland, southern Kazakhstan, western parts of the Chiangnan Belt, south China as well as northern 


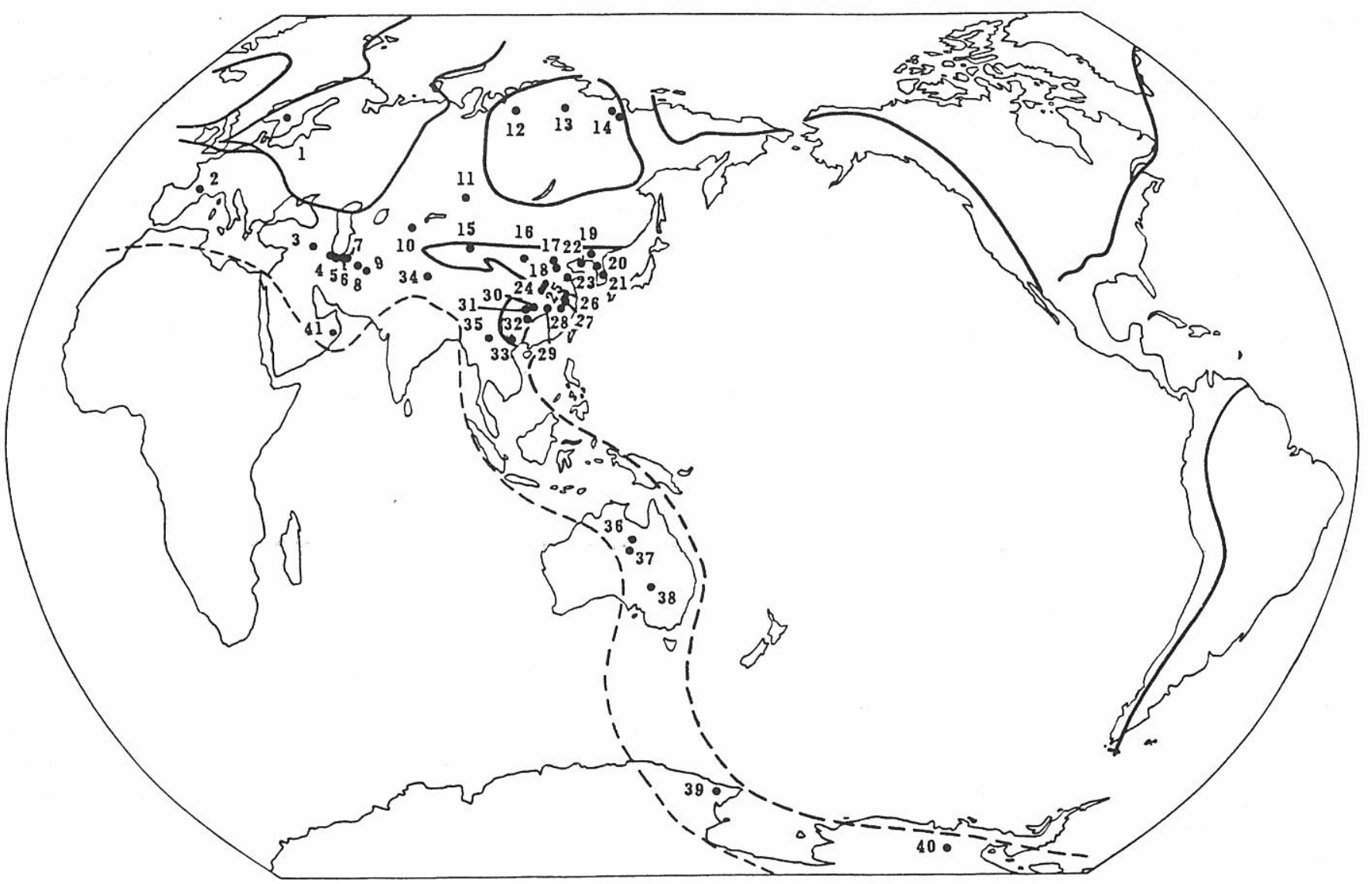

Figure 3. Biogeography of Damesellioidea trilobites (late Middle to early Late Cambrian). 1. Djupadalen, Västergötland, Sweden. Palaeadotes, Paradamesella (Westergård, 1947; Daily and Jago, 1975). 2. Montagne Noire, South France. Palaeadotes (Feist and Courtessole, 1984). 3. Southeastern Turkey. Palaeadotes (Dean, Monod and Perincek, 1981). 4. Qanli Chapoghlu, northern Iran. Palaeadotes (Kushan, 1973). 5. Abhar, northern Iran.Palaeadotes (Kushan, 1973). 6. Shahmirzad, northern Iran. Palaeadotes (Kushan, 1973). 7. Mila Kuh, northern Iran. Palaeadotes (Kushan, 1973). 8. Taraka, West Herat, Afghanistan. Damesella, Palaeadotes (Wolfart, 1983). 9. Surkh Bum, Afghanistan. Airaspis, Blackwelderia (Wolfart, 1974b). 10. Malyj Karatau, southern Kazakhstan. Prodamesella, Palaeadotes, Paradamesops, Blackwelderia, Paradamesella (Ergaliev, 1980). 11. Salair, Altai-Sayan, Russia. Damesella, Palaeadotes, Paradamesella (Poletaeva, 1960; Peng, 1987). 12. Norilsk, northern Siberia. Palaeadotes (Astashkin et al., 1991). 13. Khatanga, northern Siberia. Palaeadotes (Astashkin et al., 1991). 14. Khara-Ulakh, northern Siberia. Palaeadotes (Astashkin et al., 1991). 15. Qurug Tagh, Xinjiang, western China. Damesella, Paradamesops, Palaeadotes (Zhang, 1981). 16. Alashan-Zuoqi, Inner Mongolia. Blackwelderia, Drepanura, Dorypygella (Zhou and Zheng, 1980). 17. Northern Shansi, China. Taitzehoia, Stephanocare, Damesella (Zhang and Wang, 1985 ). 18. Taihang Mountains, North China. Drepanura, Damesops (Zhang and Wang, 1985). 19. Taizihe, Northeast China. Drepanura, Damesella, Blackwelderia, Stephanocare, Taitzehoia, Teinistion, Shantungia (Chang, 1988). 20. North Korea. Blackwelderia, Damesella (Chang, 1988). 21. South Korea. Stephanocare, Damesella, Blackwelderia, Drepanura, Bergeronites (Chang, 1988). 22. Liaodong Peninsula, China. Drepanura, Bergeronites, Damesella Blackwelderia, Dorypygella, Teinistion, Shantungia, Parashantungia, Taitzehoia, Chiawangella, Paramenomonia (Chang, 1988). 23. Shandong, China. Drepanura, Bergeronites, Stephanocare, Damesella, Blackwelderia, Dorypygella, Teinistion, Shantungia, Metashantungia (Chang, 1988). 24. Western Henan, China. Drepanura, Teinistion, Blackwelderia (Chang et al., 1995). 25. Xichuan, Southwest Henan, China. Palaeadotes, Paradamesops (Yang et al., 1991). 26. Chuxian, Anhui, China. Palaeadotes (Lu and Zhu, 1980). 27. Guichi, Southern Anhui, China. Paradamesella, Palaeadotes, Paradamesops (Qiu et al., 1983). 28. Jiangshan, Zhejiang, China. Palaeadotes, Paradamesella (Lu and Lin, 1989). 29. Xianfeng, Hubei, China. Fengduia (Lu et al., 1974; Chang et al., 1980 ). 30. Taoyuan, Hunan, China. Palaeadotes (Peng, 1987). 31. Western Hunan, China. Paradamesops, Palaeadotes, Dorypygella, Teinistion, Paradamesella, Protaitzehoia (Peng, 1987). 32. Boderland between Hunan and Guizhou, China. Palaeadotes, Protaitzehoia, Paradamesella (Yang, 1978). 33. Southeast Yunnan, China. Damesella, Blackwelderia, Drepanura, Stephanocare (Luo, 1984). 34. Zanskar, Ladakh, northern India. Blackwelderia (Whittington, 1986; Jell, 1986). 35. Baoshan, western Yunnan, China. Blackwelderia, Palaeadotes, Blackwelderoides (Luo, 1984, 1985). 36. Mungerebar-Mindyalla Area, northwestern Queensland, Australia. Meringaspis, Damesella, Palaeadotes, Dipentaspis, Blackwelderia, Stephanocare (Öpik, 1967). 37. Glenormiston- 
and southern parts of Tienshan, Xinjiang (western China) inhabited open-shelf or upper part of the open-shelf facies. Typical paradoxidoid trilobites lived in deep, cool water (Babcock, 1994). Sea level rise resulted in increasing depth of sea-water in the Mediterranean region and Central Europe during the Middle Cambrian time. Paradoxidoidea trilobites were certain to flourish. This was the reason why the warm shallow shelf trilobite faunas of eastern Asiatic affinities entirely disappeared in the Mediterranean region and Central Europe during the Middle Cambrian. This biological event took place perhaps in the late Early Cambrian.

On the North China Platform the warm shallow shelf benthic Middle Cambrian trilobite faunas, including Ptychopariidae, Proasaphiscidae, Sunaspidae, Inouyiidae, Crepicephalidae, Anomocarellidae, Dolichometopidae, Dorypygidae, Lisaniidae and Damesellidae, occurred in limestones, oolitic limestones and shales. A few species of Peronopsis, Hypagnostus, Baltagnostus and Iniospheniscus and Ptychagnostus sinicus occurred in association with those Middle Cambrian trilobites in the eastern Subprovince of the North China Platform (Chang and Jell, 1987). It deserves to be mentioned that a few eurytopic genera of those polymerid trilobites from North China occurred in the slope biofacies with cosmopolitan agnostid genera in South and western China as well as Australia. They are, primarily Fuchouia, Amphoton, Dorypyge, Lisania, Damesella, Blackwelderia and Stephanocare.

In South China, within the slope biofacies the early Middle Cambrian clastics and the late Middle Cambrian carbonate rocks contain many genera and species of Oryctocephalidae and agnostids, such as Oryctocephalus, Ptychagnostus gibbus, Ptychagnostus atavus, Hypagnostus pavifrons, Ptychagnostus punctuosus, Goniagnostus nathorsti and Lejopyge laevigata Zones by which the Middle Cambrian zonal standard has been established in Australia, China and Kazakhstan. Some important polymerid genera in the slope biofacies are Kaotaia, Oryctocephalus, Xystridura, Prohedinia, Centropleura, Fuchouia, Wanshania and early pandemic damesellids. These trilobites both in shallow shelf or slope biofacies are the chief component parts of the Middle Cambrian of the Perigondwana Realm. It should be mentioned that rich agnostid and polymerid trilobites associations in the slope biofacies of the Perigondwana Faunal Realm of Asia may be regarded as the equivalent to the upper part of the open-shelf area, or the carbonate slope apron, whereas the Perigondwanan Mediterranean region represents the lower part of the open-shelf, or the deep outermost shelf during the Middle Cambrian. The absence of Ptychagnostidae and the scarcity of agnostids in general around the Mediterranean region and Central Europe indicates ecological and environmental difference from that of the upper part of the open-shelf area.
Condylopyge and Pleuroctenium which occurred in the Mediterranean region, Central and Northern Europe, England, Newfoundland and northern and southeastern Siberia probably represent the deep water agnostid trilobites; they have not been found in China. Distribution of agnostid trilobites in China, as with polymerid trilobites, was controlled by depth and temperature; and three different ecologic environments (shallow-shelf, slope biofacies and deep water) can be recognized.

Only 9 genera of agnostids (Peronopsis, Hypagnostus, Pseudoperonopsis, Ptychagnostus, Iniospheniscus, Diplagnostus, Kormagnostus, Formosagnostus and Baltagonstus) have been described and illustrated from the North China Platform (Sun, 1989), but only Peronopsis and Hypagnostus are abundant in both limestones and shales. The others are few in species and rare.

In the Huaqiao Formation at Paibi, Huayuan County, western Hunan, late Middle Cambrian agnostid trilobites of the slope biofacies in the marginal part of the Yangtze Platform (Song, 1989) include 14 genera (Connagnostus, Diplagnostus, Linguagnostus, Oidalagnostus, Proagnostus, Clavagnostus, Hypagnostus, Peratagnostus, Valenagnostus, Acmarhachis, Goniagnostus, Lejopyge, Ptychagnostus and Toragnostus) and 23 species, ranging from the Ptychagnostus atavus to Lejopyge laevigata Zones. They are quite different from the agnostid trilobites in the shallow-shelf on the North China Platform. It is evident that the controlling factor for the faunal difference is the depth and temperature of sea water.

At Taizimiao, Xinshao County, $240 \mathrm{~km}$ southeast of Paibi village, Huayuan County, western Hunan, Centropleura rotundata Liu and Zhang, 1979 and Centropleura angustata Westergård, 1950 have been discovered in late Middle Cambrian shale beds (Liu and Zhang, 1979; Liu, 1982). Perhaps the two agnostid genera mentioned above will be discovered in the Middle Cambrian shales in this area. A second occurrence of Centropleura in China is in northern Tienshan, Xinjiang (Xiang and Zhang, 1985); about 1,260 km east of this site, Centropleura also appears in the Beishan area of northern Gansu (Liu and Zhang, 1979). The Perigondwana Realm during the Middle Cambrian includes present-day eastern, central, southern and southeastern Asia, Australia and Antarctica; the Mediterranean region and Central Europe may be affiliated with the Acado-Baltic Faunal Realm.

\section{BIOGEOGRAPHY OF DAMESELLIDAE (LATE CHANGHIAN AND KUSHANIAN STAGES) TRILOBITES}

(Fig. 3). The Damesellidae includes 43 genera belonging to 5 subfamilies. Genera of this superfamily have a narrow to broad-based glabella, preglabellar field

Sylvester Creek Area, northwestern Queensland, Australia. Cyrtoprora, Teinistion, Palaeadotes, Dipyrgotes (Öpik, 1967). 38. Western New South Wales, Australia. Blackwelderia, Palaeadotes (Wang et al., 1989). 39. North Victoria Land, Antarctica. Palaeadotes (Cooper et al., 1982). 40. Ellsworth Mountains, Antarctica. Palaeadotes, Damesella (Jago and Webers, 1992). 41. Qarn Mahatta Humaid, Oman. Fengduia (=Dipyrgotes, Fortey, 1994). 


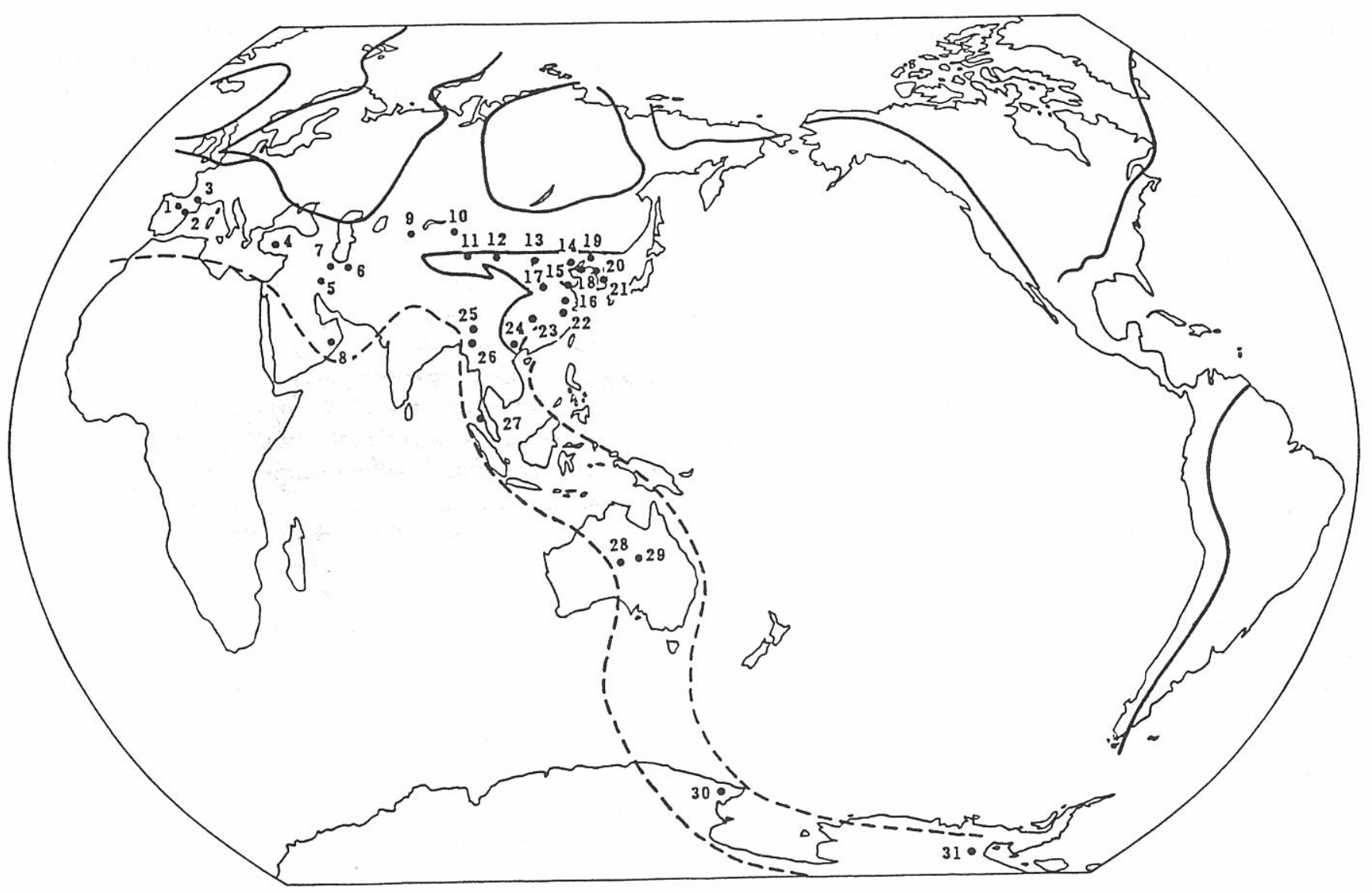

Figure 4. Biogeography of Changshanian and Fengshanian Stages (middle and late Late Cambrian). 1. Logroño and Burgos provinces, northeastern Spain. Maladioidella, Langyashania, Lajishanaspis, Pagodia (Shergold, Liñán and Palacios, 1983). 2. Zaragoza province, northeastern Spain. Parachangshania, Pagodia (Shergold and Sdzuy, 1991). 3. Montagne Noire, South France. Prochuangia (Feist and Courtessole, 1984). 4. Sultan Dag, southwestern Turkey. Maladioidella (Shergold and Sdzuy, 1984). 5. Bakhtiari Geb., southwestern Iran. Saukia, Chuangia, Maladioidella (King, 1937). 6. Eastern part of the Alborz gebirge, North Iran. Chuangia, Prochuangia, Paracoosia, Eokaolishania, Chuangiella, Pagodia, Saukia, Alborsella, Koldiniella, Wuhuia, Stigmatoa, Torifera (Kushan, 1973; Wittke, 1984). 7. Qanli-Chapoglu, Alborz Mountains, west of Tehran, Iran. Prochuangia, Eokaolishania, Luyanhaoia, Koldiniella, Paracoosia (Wittke, 1984). 8. Qarn Mahatta Humaid, Oman. Eosaukia, Yokusenia, Prochuangia, Afghanocare, Maladioidella (Fortey, 1994). 9. Malyj Karatau, southern Kazakhstan. Most genera of the Changshanian and Fengshanian ages are the same as the eastern Tienshan within the Chinese Territory, or as the western Hunan (Ergaliev, 1980; Lin et al., 1990; Peng, 1992). 10. Huocheng, northwestern Xinjiang, western China. Bulbolenus, Lotagnostus punctatus, Agnostotes, Glyptagnostus reticulatus (Xiang and Zhang, 1985). 11. Qurug Tagh, central Xinjiang, western China. Lotagnostus hedini, Lotagnostus asiaticus, Hedinaspis, Prochuangia (Lin et al., 1990). 12. Beishan, Gansu, western China. Lotagnostus hedini, Charchaqia, Hedinaspis, Glyptagnostus reticulatus (Lin et al., 1990). 13. Hangula, western Inner Mongolia, China. Charchaqia, Hedinaspis, Diceratopyge, Glyptagnostus reticulatus (Lu et al., 1981). 14. Tangshan, northeastern Hebei, China. Saukia, Ptychaspis, Kaolishania, Maladioidella, Changshania, Chuangia (Zhu and Wittke, 1989). 15. Central Shandong, eastern China. genera of Saukiidae and Ptychaspididae, Kaolishania, Maladioidella, Changshania, Chuangia (Chang, 1988). 16. Huainan, Anhui, China. with rocks of Changshanian and Fengshanian ages (Chang, 1988). 17. Dengfeng, central Henan, China. Changia, Changshania, Chuangia (Chang, 1988) 18. Liaodong Peninsula, Liaoning, northeastern China. genera of Saukiidae, Ptychaspididae and Kaolishaniidae, Changshania, Chuangia (Chang, 1988). 19. Taizihe Valley, Liaoning, northeastern China. genera of Saukiidae, Ptychaspididae and Kaolishaniidae, Changshania, Chuangia (Chang, 1988; Qian, 1994). 20. Chosan area, North Korea. Ptychaspis, Kaolishania, Changshania, Chuangia (Chang, 1988). 21. Southern Korea. genera of Saukiidae, Ptychaspididae and Kaolishaniidae, Changshania, Chuangia (Chang, 1988). 22. Western Zhejiang, eastern China. Lotagnostus punctatus, L. asiaticus, Hedinaspis, Charchaqia, Lophosaukia, Agnostotes (Pseudoglyptagnostus), Glyptagnostus reticulatus, Erixanium (Lu and Lin, 1989). 23. Western Hunan, South China. Lotagnostus, Glyptagnostus, Agnostotes, Stigmatoa, Lorrettina, Wuhuia, Maladioidella, Saukia, Mictosaukia, Lophosaukia, Eugonocare, Chuangia, Pagodia, Prochuangia, Peichiashania, Yuepingia, Charchaqia, Hedinaspis (Peng, 1992). 24. Southeastern Yunnan, China. Chuangia, Irvingella, Kaolishania, Saukia, Prosaukia, Ptychaspis, Pagodia, (Luo, 1984; Chang, 1988). 25. Batang, western Sichuan, 
usually narrow or absent, genal spines of variable length or absent, thorax with 12 segments, pygidium with 2 to 11 pairs of pygidial spines of variable length and smooth or granulose exoskeleton. The origin of this group of trilobites is not known, but it may have evolved from an older ptychoparioid trilobite. This family first appeared in the late Middle Cambrian, approximately in the Hypagnostus parvifrons, or Ptychagnostus punctuosus Zone (Chang, 1957; Song, 1989), flourished from the Damesella Zone to the Drepanura Zone, and disappeared entirely at the end of the Kushanian, or Mindyallan. In early 1940s, palaeontologists considered this family confined to eastern and southeastern Asia (Kobayashi, 1941, 1942). In recent years more information has come from many parts of the world (Poletaeva, 1960; Öpik, 1967; Kushan, 1973; Wolfart, 1974b; Daily and Jago, 1975; Ergaliev, 1980; Dean et al., 1981; Feist and Courtessole, 1984; Jell, 1986; Whittington, 1986; Kobayashi, 1987b; Astashkin et al., 1991; Jago and Webers, 1992; Fortey, 1994). Therefore, a wide geographical distribution is known. It includes not only eastern and southeastern Asia but also central and south Asia, (Kazakhstan, Himalaya, Afghanistan, Iran, Oman), Salair (southwestern Siberia), northern Siberia, Turkey, Sweden, South France, Australia and Antarctica. Except Sweden and northern Siberia, all areas fitted in with the Perigondwana Realm during the late Middle to early Late Cambrian.

Most genera of the Damesellidae lived on the warm shallow-shelf of the North China Carbonate Platform, whereas those within the Chiangnan Belt inhabited the open-shelf biofacies. The former include Damesella, Blackwelderia, Stephanocare, Fengduia, Parablackwelderia, Prodamesella, Taitzuheia, Liuheaspis, Pingquania, Pionaspis, Xintaia, Taihangshania, Guancenshania, Drepanura, Bergeronites, Teinistion, Dorypygella, Shantungia, Metashantungia, Parashantungia, Chiawangella, Paramenomonia, Jiawangaspis, Haibowania, Eodamesella, Blackwelderiella and Neoblackwelderia (65\% of this family); the latter comprise Dipyrgotes, Dipentaspis, Meringaspis, Paradamesops, Paradamesella, Protaitzuheia, Cyrtoprura, Palaeadotes, Pseudobergeronites and Histiomona (about 35\% of the Family Damesellidae), which are entirely absent in the shallowshelf area of the North China Platform. Some platform eurytopic genera, i.e., Damesella, Blackwelderia, Prodamesella, Stephanocare, Teinistion and Dorypygella, may also occur in the slope biofacies. Palaeadotes has a wide geographic distribution in the slope biofacies, or open-shelf area of China (Chiangnan Belt, western Yunnan and Qurugtagh of Xinjiang), Australia, Antarctica (North Victoria Land, Ellesworth Mountains), Kazakhstan, Salair (southwestern Siberia), northern Siberia, northern Iran, eastern Turkey, southern France and southern Sweden. A similar case is Paradamesella which has been found in western Hunan, southern Anhui, Salair, southwestern Siberia and Southern Sweden (Chang, 1996). Drepanura and Bergeronites are endemic genera confined to the warm shallow-shelf area of the North China and Yangtze Platforms. No genus of this superfamily immigrated into the Mediterranean region, or Central Europe, during the late Middle Cambrian.

\section{LATE CAMBRIAN (CHANGSHANIAN AND FENGSHANIAN) BIOGEOGRAPHY OF THE PERIGONDWANA REALM}

(Fig. 4). Cambrian biogeography of the Perigondwana Realm for the middle and late Upper Cambrian should be defined on the Leiostegoidea (Chuangia, Prochuangia, Kaolishania, Paichiashania, Pagodia), Ptychaspidioidea (Ptychaspis, Changia, Saukia, Prosaukia, Mictosaukia and other saukiid genera) and Yokusenia, Paracoosia, Changshanocephalus, Parachangshania, Maladioidella, Wuhuia and Lorrettina. These genera mentioned above inhabited the shallow-shelf area of the North China Platform. Chuangia, Prochuangia, Yokusenia, Paracoosia, Changshanocephalus, Kaolishania and Maladioidella are Changshanian, while other genera are of the Fengshanian. Pagodia, Wuhuia and Lorrettina have a stratigraphic range from Changshanian to Fengshanian.

Trilobites faunas which lived in the open-shelf area are Stigmatoa, Erixanium, Paraacidaspis, Archikainella, Hedinaspis, Charchaqia, Irvingella, Lophosaukia, Olenaspella, Eugonocare, Pseudeugonocare, Euloma (Archaeuloma), Shergoldia, Glyptagnostus, Rhaptagnostus, Agnostotes, A. (Pseudoglyptagnostus) and Lotagnostus punctatus. Genera in the open-shelf area of Gondwana and Perigondwana were distributed in China, Australia, southeast Asia, Iran and Oman. A few Changshanian genera of eastern Asiatic affinities, for instance, Maladioidella, Prochuangia, Pagodia, Lajishanaspis, Langyashania, Parachangshania and Olentella, may occur in Turkey, South France, Spain or Morocco. So far, there is no record of Fengshanian trilobites in the Mediterranean region or Central Europe. Late Cambrian (Kushanian to Fengshanian) trilobites of eastern Asiatic affinities have

China. Mictosaukia, Haniwa (Chang, 1988). 26. Paoshan, western Yunnan, China. Chuangia, Kaolishania, Mansuyia, Changia, Lophosaukia, Mictosaukia (Luo, 1985; Chang, 1988). 27. Tarutao Island, Thailand. Prosaukia, Lichengia, Eosaukia, Lophosaukia, Changia, Parakoldinioidia, Shergoldia (Shergold et al., 1988). 28. Amadeus Basin, Northern Territory, Australia. Eosaukia, Mictosaukia, Sinosaukia, Platysaukia, Lichengia, Thailandium, Changia, Shergoldia, Mansuyia (Shergold, 1991). 29. Boulia and Duchess, western Queensland, Australia. Lophosaukia, Kaolishania, Mansuyia, Kaolishaniella, Wuhuia, Lorrettina, Maladioidella, Taishania, Prosaukia, Wentsuia, Eugonocare, Stigmatoa, Erixanium, Agnostotes, Prochuangia, Peichiashania (Öpik, 1963; Shergold, 1971, 1980). 30. North Victoria Land, Antarctica. Prochuangia, Stigmatoa, Olentella, (Shergold et al., 1976; Shergold and Cooper, 1985; Cooper et al., 1982). 31. Ellsworth Mountains, West Antarctica. Stigmatoa, Erixanium, Eugonocare, Changshanocephalus, Prochuangia, (Shergold and Webers, 1992). 
been recorded from Iran and Oman, both to the east of the Mediterranean region (King, 1937; Kushan, 1973; Wolfart, 1974b; Wittke, 1984; Fortey, 1994).

Judging from the distribution of eastern Asiatic trilobite genera in the Mediterranean region during the Late Cambrian, gradually lowering of sea level took place at the end of the late Middle Cambrian, and trilobites of eastern Asiatic affinities withdrew completely from southern Europe at the beginning of the Fengshanian.

\section{THE BOUNDARY BETWEEN THE PERIGONDWANA AND THE ACADO- BALTIC FAUNAL REALMS DURING THE EARLY AND LATE CAMBRIAN IN WESTERN EUROPE}

As mentioned above, Early Cambrian redlichioid trilobites have been found in Morocco, Spain, South France, Sardinia and Germany (Doberlug and Görlitz). About $200 \mathrm{~km}$ south of Doberlug is Central Bohemia where neither redlichioid nor olenelloid trilobites have been found; ca. $620 \mathrm{~km}$ east of Doberlug are the Holy Cross Mountains of Poland where the Cambrian rocks are situated on the southern marginal part of the East European Platform and trilobite faunas including Early to Late Cambrian are of typical Acado-Baltic type; about $400 \mathrm{~km}$ north of Doberlug is the southern marginal parts of Scandinavia which is the nominate site for the typical Cambrian Acado-Baltic faunas. As mentioned earlier, Doberlug is the northernmost locality for the redlichioid Dolerolichia in Europe, and Görlitz for the Early Cambrian trilobite Ferralsia which is probably a junior synonym of the Chinese Palaeolenus.

From the tectonic map of western Europe (Naylor and Mounteney, 1975), the western and southwestern margins of the Eastern European Platform were surrounded by Caledonides. To the south, the margin of the Caledonian chain is abruptly terminated by the cross-cutting folds of the west-east younger Hercynian chain. Doberlug and Görlitz are situated just south of the boundary between the Caledonian and the Hercynian Belts. This boundary may represent the northern margin of the Mediterranean region, or Perigondwana Realm, during the Early and Late Cambrian in western Europe, because on both sides of this boundary there are different Early and Late Cambrian trilobite faunas, as well as Ordovician trilobites and acritarchs (Li, 1987; Zhou and Dean, 1989). This boundary may be regarded as equivalent to the "Tornquist Sea" in western Europe already mentioned by Cocks and Fortey (1982) and Fortey and Cocks (1988).

\section{CAMBRIAN PALAEOGEOGRAPHY OF THE NEAR AND MIDDLE EAST}

Fortey (1994) described the Late Cambrian trilobites of Oman and provided a simplified Cambrian palaeogeographic map of the Near and Middle East. It shows a continuous depositional parttern of continental or littoral shallow-shelf limestone, sandstone and dolomite; open-shelf limestone and marl, and deep water shale and sandstone areas within a distance of $1,650 \mathrm{~km}$ in the west and $2,500 \mathrm{~km}$ in the east from the Arabian Peninsula northward to Turkey, or northeastward to the northern border between Iran and Afghanistan. Trilobite faunas of Oman, southwest Iran, northern Iran and Turkey represent to each of the depositional environments mentioned above. For example, Torifera, Fengduia (=Dipyrgotes), Paracoosia, Prochuangia, Maladioidella, Yokusenia and Eosaukia from Oman, and Redlichia and ptychopariid trilobites from southwest Iran, are all of the shallow-shelf biofacies of the Perigondwana Realm, whereas Palaeadotes, Dorypyge and Cheildonocephalus from the Alborz Mountains of northern Iran are of slope or open-shelf biofacies. Protolenus, Paradoxides and Badulesia in Turkey are of deep water biofacies. This continuous distribution of the Cambrian litho- and biofacies in the Near and Middle East convinces me that a wide Tethyan Ocean did not exist in the Early Palaeozoic as I have argued repeatedly (Chang, 1980, 1987, 1989). From faunal evidence, a relatively narrow and deep geoclinal belt existed which extended from southern Europe, eastward through Turkey, northern Iran or the Caucasus, and northern Afghanistan to the Himalayan region (Jell, 1986; Whittington, 1986; Reed, 1910). This belt may be connected with the eastern Australian geoclinal belt and the transitional belt between eastern and western Antarctica, via southeast Asia. Judging by the thick sequences of Cambrian sandstone and evaporites on the margins of Gondwana in the Middle East, it is possible that West Yunnan and Malay Peninsula, Iran, Afghanistan, Pakistan and Burma may be also parts of Gondwanaland.

\section{ACKNOWLEDGEMENTS}

I would like to thank Professor A. R. Palmer, Institute for Cambrian Studies, Boulder (U.S.A.), and Dr. P. A. Jell, Queensland Museum, Brisbane (Australia) for patiently reading and correction of the manuscript, and for many excellent suggestions; to José A. Gámez Vintaned, Universidad de Extremadura at Badajoz (Spain), and Professor E. Liñán, Universidad de Zaragoza (Spain), for helpful comments on the original manuscript and for editorial work that has improved the text.

\section{REFERENCES}

Abdulin, A. A. and Chakabaev, E. E. 1984. Geology and phosphorite deposits in Malyj Karatau Ridge. Guidebook Excursions No. 045A and No. 101A. XXVII International Geological Congress, Moscow, 1984, 1-80.

Abdulin, A. A., Apollonov, M. K. and Ergaliev, G. Kh. (Eds.) 1990. Guide-book. Third International Symposium on the Cambrian System. Excursion 2. 10-16 August 1990. Kazakh SSR. Malyj Karatau. Academy of Sciences of Kazakh SSR, Alma-Ata. 62 pp. 
Astashkin, V. A., Pegel', T. V., Repina, L. N., Rozanov, A. Yu., Shabanov, Yu. Ya., Zhuravlev, A. Yu., Sukhov, S. S. and Sundukov, V. M. 1991. The Cambrian System on the Siberian Platform. International Union of Geological Sciences Publication, 27, 1-133.

Babcock, L. E. 1994. Systematics and phylogenetics of polymeroid trilobites from the Henson Gletscher and Cap Stanton formations (Middle Cambrian), North Greenland. In: Paleontology, stratigraphy and environmental setting of Middle Cambrian outer shelf deposits, North Greenland. (Ed. J. S. Peel). Grønlands geologiske Unders $\phi$ gelse, Bulletin, 169, 79-127.

Chang, W. T. 1957. Preliminary note on the Lower and Middle Cambrian stratigraphy of Poshan, central Shantung. Acta Palaeontologica Sinica, 5, 13-31. [In Chinese with English abstract.]

Chang, W. T. 1966. On the classification of Redlichiacea, with description of new families and new genera. Acta Palaeontologica Sinica, 14, 135-184. [In Chinese with English abstract.]

Chang, W. T. 1980. A review of the Cambrian of China. Journal of the Geological Society of Australia, 27, 137150.

Chang, W. T. 1987. Tethys in the early Palaeozoic. In: (Ed. K. G. McKenzie). Proceedings of the International Symposium on Shallow Tethys 2, 61-64.

Chang, W. T. 1988. Correlation chart and explanatory notes. In: The Cambrian System in Eastern Asia. (Eds. J. H. Shergold and A. R. Palmer). International Union of Geological Sciences Publication, 24, 1-81.

Chang, W. T. 1989. World Cambrian biogeography. In: Development in Geosciences. Academia Sinica Contribution to 28th International Geological Congress, 1989, Washington, D.C., USA. Science Press, Beijing, 209-220.

Chang, W. T. 1996. Notes on the Swedish Drepanura eremita Westergård, 1947. In: Centennial Memorial Volume of Prof. Sun Yunzhu (Y. C. Sun). Palaeontology and Stratigraphy. (Eds. H. Z. Wang and X. L. Wang). Chinese University of Geosciences Press, Beijing, 69-73.

Chang [Zhang] Wen-tang and Jell, P. A. 1987. Cambrian trilobites of North China: Chinese Cambrian trilobites housed in the Smithsonian Institution. Science Press, Beijing. 459 pp.

Chang [Zhang] Wen-tang, Lu Yan-hao, Zhu Zhao-ling, Qian Yi-yuan, Lin Huan-ling, Zhou Zhi-yi, Zhang Sen-gui and Yuan Jin-liang. 1980. Cambrian trilobite faunas of Southwest China. Palaeontologia Sinica, 159, New Series B, 16, 1-497. [In Chinese with English summary.]

Chang [Zhang] Wen-tang, Xiang Li-wen, Liu Yin-huan and Meng Xian-son. 1995. Cambrian stratigraphy and trilobites from Henan. Palaeontologia Cathayana, 6, 191.

Chang, W. T., Repina, L. N. and Geyer, G. 1997. Suborder Redlichiina Richter, 1932. In: Treatise on Invertebrate Paleontology. Part O. Arthropoda 1. Trilobita, Revised. Volume 1: Introduction, Order Agnostida, Order Redlichiida. (Ed. R. L. Kaesler). The Geological Society of America, Inc. and the University of Kansas, Boulder, Lawrence, 429-470.
Cobbold, E. S. 1935a. A new genus of Trilobita and a new species of Conchostraca from the Cambrian of Carteret region N.W. France. Annals and Magazine of Natural History, Series 10, 15, 381-392.

Cobbold, E. S. 1935b. Lower Cambrian faunas from Hérault (France). Annals and Magazine of Natural History, Series 10, 16, 25-48.

Cocks, L. R. M. and Fortey, R. A. 1982. Faunal evidence for oceanic separations in the Palaeozoic of Britain. Journal of the Geological Society, 139, 465-478.

Cooper, R. A. and Shergold, J. H. 1991. Palaeozoic invertebrates of Antarctica. In: The Geology of Antarctica. (Ed. R. J. Tingey). Oxford Monographs on Geology and Geophysics, 17, Oxford Science Publications, Clarendon Press, Oxford, 455-486.

Cooper, R. A., Jago, J. B., MacKinnon, D. I., Shergold, J. H., \& Vidal, G. 1982. Late Precambrian and Cambrian fossils from Northern Victoria Land and their stratigraphic implications. In: Antarctic GeosciencesSymposium on Antarctic Geology and Geophysics, Madison, Wisconsin, USA, August 22-27, 1977. (Ed. C. Craddock). The University of Wisconsin Press, Madison, 629-633.

Courtessole, R. et Jago, J. B. 1980. Biostratigraphie du Cambrien inférieur du Cabardes (versant sud de la Montagne Noire, France Méridionale). Mémoire de la Société d'Études Scientifiques de l'Aude, 1-26.

Cowie, J. W. 1971. Lower Cambrian faunal provinces. In: Faunal provinces in space and time. (Eds. F. A. Middlemiss, P. W. Rawson and G. Newall). Geological Journal Special Issue, 4, Seel House Press, Liverpool, 31-46.

Daily, B. and Jago, J. B. 1975. The trilobite Lejopyge Hawle and Corda and the Middle-Upper Cambrian boundary. Palaeontology, 18, 527-550.

Dean, W. T. 1982. Middle Cambrian trilobites from the Sosink Formation, Derik-Mardin district, southeastern Turkey. Bulletin of the British Museum (Natural History), Geology Series, 36 (1), 1-41.

Dean, W. T., Monod, O. and Perincek, D. 1981. Correlation of Cambrian and Ordovician rocks in southeastern Turkey. Petroleum Activities at the 100th Year (100 Yilda Petrol Faaliyeti). Türkiye Cumhuriyet Petrol Isleri Genel Müdürlügü Dergisi 25, 269-291 [in English], 293300 [in Turkish].

Debrenne, F. 1992. Diversification of Archaeocyatha. In: Origin and Early Evolution of the Metazoa. (Eds. J. H. Lipps and P. W. Signor). Plenum Press, New York, 425443.

Dumicz, M., Tomczykowa, E. and Wójcik, L. 1970. On the occurrence of Middle Cambrian trilobites in the Khobdo Region (western Mongolia). Rocznik Polskiego Towarzystwa Geologicznego, Annales de la Société Géologique de Pologne, 40, 287-310.

Ergaliev, G. Kh. 1980. Trilobity srednego i verkhnego kembrija Malogo Karatau. [Middle and Upper Cambrian trilobites of Malyj Karatau.] Nauka, Kazakh SSR, Alma Ata. 212 pp. [In Russian.]

Feist, G. et Courtessole, R. 1984. Découverte de Cambrien supériour à trilobites de type estasiatique dans la 
Montagne Noire (France méridionale). Comptes Rendus de l'Académie des Sciences, Série II, 298 (5), 177-182.

Fortey, R. A. 1994. Late Cambrian trilobites from the Sultanate of Oman. Neues Jahrbuch für Geologie und Paläontologie, Abhandlungen, 194 (1), 25-53.

Fortey, R. A. and Cocks, L. R. M. 1988. Arenig to Llandovery faunal distributions in the Caledonides. In: The Caledonian-Appalachian Orogen. (Eds. A. L. Harris and D. J. Fettes). Geological Society Special Publication, 38, 233-246.

Fortey, R. A. and Rushton, A. W. A. 1976. Chelidonocephalus trilobite fauna from the Cambrian of Iran. Bulletin of the British Museum (Natural History), Geology Series, 27 (4), 321-340.

Geyer, G. and Elicki, O. 1995. Lower Cambrian trilobites from the Görlitz Synclinorium (Germany) - review and new results. Paläontologische Zeitschrift, 69 (1/2), 87 119.

Henningsmoen, G. 1958. Los trilobites de las capas de Saukianda, Cambrico inferior, en Andalucía. Estudios Geológicos, 14 (1957), 251-272.

Hill, D. 1972. Treatise on Invertebrate Paleontology. Part E (Archaeocyatha. Revised). (Ed. C. Teichert). Geological Society of America and University of Kansas Press, Boulder, Lawrence. XXX+158 pp.

Hupé, P. 1953. Contribution à l'étude du Cambrien inférieur et du Précambrien III de l'Anti-Atlas Marocain. Notes et Mémoires du Service géologique de Maroc, 103, 1-402.

Jago, J. B. and Webers, G. F. 1992. Middle Cambrian trilobites from the Ellsworth Mountains, West Antarctica. Geological Society of America Memoir, 170, 101-124.

Jell, P. A. 1986. An early Upper Cambrian trilobites faunule from Kashmir. Geological Magazine, 123 (5), 487-492.

Jell, P. A. 1990. Trilobita. In: Early Cambrian fossils from South Australia. (Auts. S. Bengtson, S. Conway Morris, B. J. Cooper, P. A. Jell and B. N. Runnegar). Association of Australasian Palaeontologists Memoir, 9, 257-322.

Keller, B. M. i Pokrovskaya, N. V. 1965. Novye dannye o vozraste fosforitov Karatau. [New on the age of Karatau phosphorites]. Izvestija AN SSSR, Serija geologicheskaja, 6, 78-91.

King, W. B. R. 1937. Cambrian trilobites from Iran (Persia). Memoirs of the Geological Survey of India, Palaeontologica Indica, (new series), 22 (5), 1-22.

King, W. B. R. 1941. The Cambrian fauna of the Salt Range of India. Records of the Geological Survey of India, 75 (1940), Professional Paper 9, 1-15.

Kobayashi, T. 1941. Studies on Cambrian trilobite genera and families (I-III). Japanese Journal of Geology and Geography, 18 (1-2), 25-40, 41-51, 59-70.

Kobayashi, T. 1942.Studies on Cambrian trilobite genera and families (IV). Japanese Journal of Geology and Geography, 18 (4), 197-212.

Kobayashi, T. 1967. The Cambro-Ordovician formations and faunas of South Korea. Part X. Stratigraphy of the Chosen Group in Korea. Sect. C. The Cambrian of eastern Asia and other part of the continent. Journal of the Faculty of Science, University of Tokyo, Section II, 16 (3), 381-535.
Kobayashi, T. 1972. Three faunal provinces in the Early Cambrian Period. Proceedings of the Japanese Academy, 48, 242-247.

Kobayashi, T. 1976. Distribution of Cambrian trilobites in the Perigondwana Sea. Proceedings of the Japanese Academy, 52 (4), 187-190.

Kobayashi, T. 1987a. On the Redlichiacea (Trilobita) and the Redlichian Province. Proceedings of the Japanese Academy, 63, 43-46.

Kobayashi, T. 1987b. On the Damesellidae (Trilobita) in eastern Asia. Proceedings of the Japanese Academy, 63, 59-62.

Korobov, M. N. 1989. Biostratigrafija i polimernye trilobity nizhnego kembrija Mongolii. [Lower Cambrian biostratigraphy and polymeroid trilobites of Mongolia.] Trudy Sovmestnoj Sovetsko-Mongol'skoj geologicheskoj ekspeditsii [The Joint Soviet-Mongolian ScientificResearch Geological Expedition Transactions], 48, 1208.

Kushan, B. 1973. Stratigraphie und Trilobitenfauna in der Mila-Formation (Mitteikambrium-Tremadoc) im AlborzGebirge (N-Iran). Palaeontographica, Abteilung A, 144, 113-165.

Lermontova, E. V. 1940. Klass Trilobity (Trilobita). [Class Trilobites (Trilobita)]. In: Atlas rukovodjashchikh form iskopaemykh faun SSSR. Tom I: Kembrij. [Atlas of the index forms of the fossil faunas of the USSR. Volume I: Cambrian.] (Ed. A. G. Vologdin). State Editorial Office for Geological Literature, Moskva, Leningrad, 112-157. [In Russian.]

Li Jun. 1987. Ordovician Acritarchs from the Meitan Formation of Guizhou Province, southwest China. Palaeontology, 30 (3), 613-634.

Lin Huan-ling, Wang Zhong-zhe, Zhang Tai-rong and Qiao Xin-dong. 1990. Cambrian System. In: Biostratigraphy of the Tarim Basin and its geological evolution. (Eds. Zhou Zhi-yi and Chen Pei-ji). Science Press, Beijing, 855. [In Chinese.]

Liñán, E. and Sdzuy, K. 1978. A trilobite from the Lower Cambrian of Córdoba (Spain) and its stratigraphical significance. Senckenbergiana lethaea, 59 (4-6), 387399.

Liu Yi-ren, 1982. Trilobita. In: The Palaeontological Atlas of Hunan. Geological Publishing House, Beijing, 290346. [In Chinese.]

Liu Yi-ren and Zhang Tai-rong. 1979. Notes on the discovery of the Middle Cambrian Centropleura in China. Geological Review, 25 (2), 1-6. [In Chinese.]

Lu Yan-hao and Lin Huan-ling. 1989. The Cambrian trilobites of western Zhejiang. Palaeontologia Sinica, 178, New Series B no. 25, 1-287. [In Chinese with English abstract.]

Lu Yan-hao and Zhu Zhao-ling. 1980. Cambrian trilobites from Chuxian-Quanjiao Region, Anhui. Memoir of the Nanjing Institue of Geology and Palaeontology, Academia Sinica, 16, 1-38. [In Chinese with English abstract.]

Lu Yan-hao, Zhang Wen-tang, Qian Yi-yuan, Zhu Zhaoling, Lin Huan-ling, Zhou Zhi-yi, Zhang Sen-gui and Wu Hong-ji. 1974. Cambrian trilobites. In: Handbook of the 
Stratigraphy and Palaeontology of SW China. Nanjing Institute of Geology and Palaeontology, Academia Sinica, Science Press, Beijing, 82-107. [In Chinese.]

Lu Yan-hao, Zhou, Z. Q. and Zhou Zhi-yi. 1981. Boundary between Cambrian and Ordovician in Hangula, western Inner Mongolia, China with description of some trilobites. Bulletin of Xi'an Institute of Geology and Mineral Resources, Chinese Academy of Geological Sciences, 2 (1), 1-18. [In Chinese with English abstract.]

Luo Hui-lin. 1984. Subdivision and correlation of the Cambrian System in southeastern Yunnan. Acta Geologica Sinica, 58 (2), 87-96. [In Chinese with English abstract.]

Luo Hui-lin. 1985. Subdivision and correlation of the Cambrian System in western Yunnan. Geology of Yunnan, 4 (1), 69-83. [In Chinese.]

Naylor, D. and Mounteney, S. N. 1975. Geology of the Northwest European Continental Shelf. Volume 1. Graham Trotman Dudley Publishers Ltd., London. 162 pp.

Öpik, A. A. 1961. The geology and palaeontology of the headwaters of the Burke River, W. Queensland. Commonwealth of Australia, Bureau of Mineral Resources, Geology and Geophysics Bulletin, 53, 1-249.

Öpik, A. A. 1963. Early Upper Cambrian fossils from Queensland. Commonwealth of Australia, Bureau of Mineral Resources, Geology and Geophysics Bulletin, 64, 1-133.

Öpik, A. A. 1967. The Mindyallan fauna of north-western Queensland. Commonwealth of Australia, Bureau of Mineral Resources, Geology and Geophysics Bulletin, 74, vol. 1 (text), 1-404, vol.2 (appendixes, plates and index), 1-166.

Öpik, A. A. 1970. Redlichia of the Ordian (Cambrian) of Northern Australia and New South Wales. Bureau of Mineral Resources, Geology and Geophysics Bulletin, 114, 1-166.

Öpik, A. A., 1975. Templetonian and Ordian Xystridurid trilobites of Australia. Bureau of Mineral Resources, Geology and Geophysics Bulletin, 121, 1-84.

Öpik, A. A. 1979. Middle Cambrian agnostids: Systematics and Biostratigraphy. Bureau of Mineral Resources, Geology and Geophysics Bulletin, 172, 1-188 (Vol. 1), pls. 1-67 (Vol. 2).

Öpik, A. A. 1982. Dolichometopid trilobites of Queensland, Northern Territory and New South Wales. Bureau of Mineral Resources, Geology and Geophysics Bulletin, 175, 1-85.

Palmer, A. R. 1968. Cambrian trilobites of East-Central Alaska. U.S. Geological Survey Professional Paper, 559. B, $1-115$.

Palmer, A. R. and Gatehouse, C. G. 1972. Early and Middle Cambrian trilobites from Antarctica. U. U.S. Geological Survey Professional Paper, 456-D, 1-37.

Palmer, A. R. and Repina, L. N. 1993. Through a glass darkly: Taxonomy, phylogeny, and biostratigraphy of the Olenellina. The University of Kansas Paleontological Contributions, New Series, 3, 1-35.

Palmer, A. R. and Rowell, A. J. 1995. Early Cambrian trilobites from the Shackleton limestone of the central
Transantarctica Mountains. Journal of Paleontology, 69 (Supplement to No. 6), The Paleontological Society Memoir 45, 1-28.

Peng Shan-chi. 1987. Early Late Cambrian stratigraphy and trilobite fauna of Taoyuan and Cili, Hunan. In: Collection of postgraduate theses, Nanjing Institute of Geology and Palaeontology, Academia Sinica, 53-134. [In Chinese with English summary.]

Peng Shan-chi. 1992. Upper Cambrian biostratigraphy and trilobite faunas of the Taoyuan and Cili area, northwestern Hunan, China. Association of Australasian Palaeontologists Memoir, 13, 1-119.

Pillola, G. L. 1991. Trilobites du Cambrien inférieur du SW de la Sardaigne, Italie. Palaeontographica Italica, 78, 1174.

Pokrovskaya, N. V. 1959. Trilobitovaja fauna i stratigrafija kembrijskikh otlozhenij Tuvy. [Trilobite fauna and stratigraphy of Cambrian strata of Tuva.] Trudy Geologicheskogo Instituta Academii nauk SSSR, 27, 1200.

Poletaeva, 0. K. 1960. Novye rody i vidy kembrijskikh trilobitov Zapadnoj Sibirri. [New genera and species of Cambrian trilobites of the Western Siberia.] In: Materialy po paleontologii i stratigrafii Zapadnoj Sibiri. [Materials on the palaeontology and stratigraphy of the Western Siberia.] (Ed. L. L. Khalfin). Trudy Sibirskogo nauchnoissledovatel'skogo instituta geologii, geogiziki $i$ mineral'nogo syr'ja, Serija Neftjanaja geologija [Transactions of the Siberian Scientific-Research Institute of Geology, Geophysics and Mineral Resources, Series Oil Geology], Leningrad, Gostoptekhizdat, 8, 50-76.

Qian Yi-yuan. 1994. Trilobites from middle Upper Cambrian (Changshanian Stage) of North and Northeast China. Palaeontologia Sinica, n. s. B, 30, 1-190. [In Chinese with English summary.]

Qiu, H. A, Lu, Y. H., Zhu, Z. L., Bi, D. C., Lin, T. R., Zhou, Z. Y., Zhang, Q. Z., Qian, Y. Y., Ju, T. Y., Han, N. R. and Wei, X. Z. 1983. Trilobita. In: Palaeontological Atlas of East China. Vol. 1, Early Palaeozoic. (Ed. Nanjing Institute of Geology and Mineral Resources, Ministry of Geology and Mineral Resources). Geological Publishing House, Beijing, 28-254.[In Chinese.]

Reed, F. R. C. 1910 The Cambrian fossils of Spiti. Memoirs of the Geological Survey of India, Palaeontologica Indica, new series, 10 (1), 1-71.

Repina, L. N. 1960. Kompleksy trilobitov nizhnego i srednego kembrija zapadnoj chasti Vostochnogo Sayana. [Trilobite assemblages from the Lower and Middle Cambrian of the western part of the Eastern Sayan.] In: Regional'naja Stratigrafija SSSR, vip. 4. (Ed. N. N. Shatsky). Trudy Geologicheskogo Instituta Akademii nauk SSSR, Academija nauk SSSR, Moskva, 171-232.

Repina, L. N. 1966. Trilobity nizhnego kembrija yuga Sibiri (nadsemejstvo Redlichioidea). Chast' I. [Lower Cambrian trilobites from the South of Siberia (superfamily Redlichioidea). Part I.] Nauka, Moskva. 204 pp. [In Russian.]

Repina, L. N. 1979. Zavisimost' morfologicheskikh priznakov ot uslovij obitanija trilobitov i otsenka ikh znachenija dlja sistematiki nadsemejstva Olenelloidea. 
[The dependence of morphological features on the trilobite habitats and the estimation of their significance for the systematics of the Superfamily Olenelloidea.] In: Sreda i zhizn' v geologicheskom proshlom: Voprosy ekostratigrafii. [Environment and life in the geological past: Problems of the ecostratigraphy.] (Eds. O. A. Betekhtina i I. T. Zhuravleva). Trudy Instituta geologii $i$ geofiziki Sibirskogo otdelenija Akademii nauk SSSR [Transactions of the Institute of Geology and Geophysics of the Siberian Branch of the USSR Academy of Sciences], 431, 11-30, 155. [In Russian.]

Repina, L. N., Khomentovsky, V. V., Zhuravleva, I. T. Rozanov, A. Yu. 1964. Biostratigrafija nizhnego kembrija Sajano-Altayskoj skladchatoj oblasti. [Lower Cambrian biostratigraphy of the Sayan Altay Foldbelt.] Nauka, Moskva. 364 pp. [In Russian.]

Richter, R. und E. Richter, E. 1941a. Die Fauna des Unterkambriums von Cala in Andalusien. Abhandlungen der Senckenbergischen Naturforschenden Gesellschaft, 455, 1-90.

Richter, R. und Richter, E. 1941b. Das Kambrium am Toten Meer und die älteste Tethys. Abhandlungen der senckenbergischen naturforschenden Gesellschaft, 460, $1-50$.

Schindewolf, O. H. und Seilacher, A. 1955. Beiträge zur kenntnis des Kambriums in der Salt Range (Pakistan). Akademie der Wissenschaften und der Literatur in Mainz, mathematisch-naturwissenschaftliche Klasse, Abhandlungen, 10, 257-446.

Sdzuy, K. 1961. Das Kambrium Spaniens. Teil II: Trilobiten. Akademie der Wissenschaften und der Literatur, Abhandlungen der mathematischnaturwissenschaftlichen Klasse, 1961 (7-8), 499-690 (217-408).

Sdzuy, K. 1962. Neue kambrische Fossilien aus Bohrungen im Gebiet von Doberlug. Geologie, 11 (9), 1087-1101.

Sdzuy, K. 1978. The Precambrian-Cambrian boundary beds in Morocco (preliminary report). Geological Magazine, 115 (2), 83-94.

Shergold, J. H. 1969. Oryctocephalidae (Trilobita: Middle Cambrian) of Australia. Bureau of Mineral Resources, Geology and Geophysics Bulletin, 104, 1-66.

Shergold, J. H. 1971. Late Upper Cambrian trilobites from the Gola Beds, western Queensland. Bureau of Mineral Resources, Geology and Geophysics Bulletin, 112, 1-87.

Shergold, J. H. 1980. Late Cambrian trilobites from the Chatsworth Limestone, western Queensland. Bureau of Mineral Resources, Geology and Geophysics Bulletin, 186, 1-111.

Shergold, J. H. 1991. Late Cambrian (Payntonian) and Early Ordovician (Late Warendian) trilobite faunas of the Amadeus Basin, central Australia. Bureau of Mineral Resources of Australia Bulletin, 237, 15-75.

Shergold, J. H. and Cooper, R. A. 1985. Late Cambrian trilobites from the Mariner Group, North Victoria Land. Bureau of Mineral Resources, Journal of Australian Geology and Geophysics, 9, 91-106.

Shergold, J. H. and Sdzuy, K. 1984. Cambrian and Early Tremadocian trilobites from Sultan Dag, central Turkey. Senckenbergiana lethaea, 65 (1-3), 51-135.
Shergold, J. H. and Sdzuy, K. 1991. Late Cambrian trilobites from the Iberian Mountains, Zaragoza Province, Spain. Beringeria, 4, 193-235.

Shergold, J. H. and Webers, G. F. 1992. Late Dresbachian (Idamean) and other trilobite faunas from the Heritage Range, Ellsworth Mountains, west Antarctica. In: Geology and Paleontology of the Ellsworth Mountains, west Antarctica. (Eds. G. F. Webers, C. Craddock and J. F. Splettstoesser). Geological Society of America Memoir, 170, 125-168.

Shergold, J. H., Cooper, R. A., Mackinnon, D. I. and Yochelson, E. L. 1976. Late Cambrian Brachiopoda, Mollusca and Trilobita from northern Victoria Land, Antarctica. Palaeontology, 19 (2), 247-291.

Shergold, J. H., Liñán, E. and Palacios, T. 1983. Late Cambrian trilobites from the Najerilla Formation, northeastern Spain. Palaeontology, 26 (1), 71-92.

Shergold, J. H., Burrett, C., Timothy, A. and Stait, B. 1988. Late Cambrian trilobites from Tarutao Island, Thailand. New Mexico Bureau of Mines and Mineral Resources, Memoir 44, 303-320.

Song Yan-ping. 1989. Upper Middle Cambrian trilobite biostratigraphy of western Hunan, China. Ph. D. Thesis, University of Kansas. 76 pp. [Unpublished.]

Sun Xiao-wen, 1989. Cambrian agnostids from the North China Platform. Palaeontologia Cathayana, 4, 53-130.

Tchernisheva, N. Ye. 1977. Novye rody trilobitov srednego kembrija Tuvy i Sibirskoj platformy. [New genera of trilobites of the Middle Cambrian of Tuva and Siberian Platform]. In: Novye vidy drevnikh rastenij $i$ bespozvonochnykh SSSR. Tom 4. [New genera of ancient plants and invertebrates of USSR. Vol. 4.] (Ed. G. A. Stukalina). Nauka, Moskva, 61-65. [In Russian.]

Thoral, M. 1935. Contribution à l'étude géologique des Monts de Lacaune et des terrains cambriens et ordoviciens de la Montagne Noire. Bulletin du Service de la Carte géologique de France, 38 (192), 319-637.

Wang, Q., Mills, K. J., Webby, B. D. and Shergold, J. H. 1989. Upper Cambrian trilobites (Mindyallan) and stratigraphy of the Kayrunnera Group, western New South Wales. Bureau of Mineral Resources Journal of Australian Geology and Geophysics, 11, 107-118.

Westergård, A. H. 1947. Supplementary notes on the Upper Cambrian trilobites of Sweden. Sveriges Geologiska Undersökning, Series C, 489 (苗sbok 41, no. 8), 1-34.

Westergård, A. H. 1950. Non-agnostidean trilobites of the Middle Cambrian of Sweden (II). Sveriges Geologiska Undersökning, Series C, 511 (̊̊rsbok 43, no. 9), 1-56.

Whittington, H. B. 1986. Late Middle Cambrian trilobites from Zanskar, Ladakh, northern India. Rivista Italiana di Paleontologia e Stratigrafia, 92 (2), 171-188.

Wittke, H. W. 1984. Middle and Upper Cambrian trilobites from Iran: their taxonomy, stratigraphy and significance for provincialism. Palaeontographica, Abteilung A, 183, 91-161.

Wolfart, R. 1974a. Die fauna (Brachiopoda, Mollusca, Trilobita) aus dem Unter-Kambrium von Kerman, Sudost Iran. Geologische Jahrbuch (Reihe B), 8, 5-70.

Wolfart, R. 1974b. Die fauna (Brachiopoda, Mollusca, Trilobita) des älteren Ober-Kambriums (Ober- 
Kushanian) von Dorah Shah Dad, Südost Iran, und Surkh Bum, Zentral-Afghanistan. Geologische Jahrbuch (Reihe B), 8, 71-184.

Wolfart, R. 1983. The Cambrian System in the Near and Middle East. International Union of Geological Sciences Publication, 15, 1-71.

Xiang Li-wen and Zhang Tai-rong. 1985. Systemic description of Cambrian trilobites. In: Stratigraphy and trilobite fauna of the Cambrian in the western part of northern Tienshan, Xinjiang. (Ed. Zi-guo Wang). Ministry of Geology and Mineral Resources, Geological Memoirs, Series 2, 4, 64-243. [In Chinese with English summary.]

Yang Jia-lu. 1978. Middle and Upper Cambrian trilobites of western Hunan and eastern Guizhou. Chinese Academy of Geological Sciences, Professional Papers of Stratigraphy and Palaeontology, 4, 1-83. [In Chinese.]

Yang Jia-lu, Yu Su-yu, Liu Gui-tao, Su Nan-miao, He Minghua, Shang Jian-guo, Zhang Hai-qing, Zhu Hong-yuan, Li Yu-jing and Yan Guo-shun. 1991. Cambrian stratigraphy, lithofacies, palaeogeography and trilobite faunas of east Qinling-Dabashan Mountains. China University of Geosciences Press, Wuhan. 192 pp. [In Chinese.]

Yuan Ke-xing and Zhang Sen-gui. 1983. Biogeographical provinces of Early Cambrian Archaeocyathids in China. Bulletin of the Nanjing Institute of Geology and Palaeontology, Academia Sinica, 6, 101-115. [In Chinese with English abstract.]
Zhang Jin-lin and Wang Shao-xin. 1985. Trilobita. In: Palaeontological Atlas of North China. Part I, Palaeozoic Volume. (Ed. Tianjin Institute of Geology and Mineral Resources, Ministry of Geology and Mineral Resource). Geological Publishing House. Beijing, 327-488 [description of species], 611-624 [alphabetical list of trilobite species], 689-713 [explanation of plates 103-147]. [In Chinese.]

Zhang Tai-rong. 1981. Trilobita. In: Palaeontological Atlas of Northwestern China. Part 1, Late Precambrian and Early Palaeozoic. (Eds. Geological Bureau and Petroleum Bureau of Xinjiang). Geological Publishing House, Beijing, 134-213. [In Chinese.]

Zhou Zi-qiang and Zheng Zhao-chang. 1980. Upper Cambrian trilobites from Helan Mountains. Bulletin of $X i^{\prime}$ an Institute of Geology and Mineral Resources, 1 (1), 60-77. [In Chinese.]

Zhou Zhi-yi and Dean, W. T. 1989. Trilobite evidence for Gondwanaland in east Asia during the Ordovician. Journal of Southeast Asian Earth Science, 3 (1-4), 131140.

Zhu Zhao-ling and Lin Huan-ling. 1983. Some Early Cambrian trilobites from the Xidashan Formatiom of Kuruktag, Xinjiang. Acta Palaeontologica Sinica, 22, (1), 21-30. [In Chinese with English abstract.]

Zhu Zhao-ling and Wittke, H. W. 1989. Upper Cambrian trilobites from Tangshan, Hebei Province, North China. Palaeontologia Cathayana, 4, 199-259. 